\title{
PENERAPAN MODEL PEMBELAJARAN KOOPERATIF TIPE PICTURE AND PICTURE UNTUK MENINGKATKAN HASIL BELAJAR MATEMATIKA SISWA KELAS IVB SDN 136 PEKANBARU
}

\author{
Fajriah Hasanah Tri Komara ${ }^{1}$, Zetra Hainul Putra ${ }^{{ }^{*}}$, Neni Hermita ${ }^{1}$ \\ Program Studi Pendidikan Guru Sekolah Dasar, \\ Fakultas Keguruan dan IImu Pendidikan, Universitas Riau, Pekanbaru, Indonesia \\ zetra.hainul.putra@lecturer.unri.ac.id
}

Received: February $07^{\text {th }}, 2020$ Revised: August $10^{\text {th }}, 2020 \quad$ Accepted: August $11^{\text {th }}, 2020$

\begin{abstract}
This research is motivated by the low mathematics learning outcomes of fourth grade students of SD Negeri 136 Pekanbaru, with an average score of 68.25 and only 17 of 40 reach the minimum completeness criteria (KKM). This research is a classroom action research (CAR) conducted aimed at improving the mathematics learning outcomes of fourth graders by implementing a cooperative model of picture and picture type. The subjects of this study were 40 fourth grade students of class IVB in 2019/2020 school year. Data collection instruments in this study were teacher activity sheets and student activities and learning outcomes. The results of this study indicate that student learning outcomes increased by $13.26 \%$ from an average of 68.25 to 77.3 in cycle I. In the second cycle it increased to $24.54 \%$ with an average of 85 . Teacher activity also increased from $75.00 \%$ with enough category in the first cycle of the first meeting to be $96.43 \%$ very good category in the second meeting of the second cycle. The results showed that the application of the Cooperative model type Picture and picture could improve the mathematics learning outcomes of class IVB students of SD Negeri 136 Pekanbaru.
\end{abstract}

Keyword: cooperative learning; learning outcomes; picture and picture; student activities; teacher activity.

\section{PENDAHULUAN}

Salah satu permasalahan yang dihadapi dunia pendidikan kita adalah kurangnya pemahaman siswa terhadap pembelajaran yang berlangsung di sekolah sehingga siswa mengalami kesulitan dalam mengikuti materi pembelajaran berikutnya. Hal yang serupa juga dijumpai pada pembelajaran matematika (Witri, Putra, \& Nurhanida, 2015; Witri, Putra, \& Gustina, 2014), padahal matematika memiliki peran yang penting dalam kehidupan dan merupakan ilmu pengetahuan yang berkembang pesat pada saat sekarang ini. 
Siswa yang menguasai pengetahuan matematika akan lebih mudah menerima pengetahuan lainnya.

Salah satu faktor penting dalam mengupayakan perbaikan dalam proses pembelajaran matematika adalah guru (Putra, 2019). Guru memiliki peran penting sebagai fasilitator dan motivator. Guru hendaknya lebih kreatif dalam memilih model pembelajaran guna mendukung siswa dalam belajar. Model pembelajaran hendaknya dapat meningkatkan hasil belajar siswa dan mencapai ketuntasan belajar siswa.

Dalam proses pembelajaran, guru mentransfer ilmu kepada siswa agar siswa dapat memahami materi yang disampaikan oleh guru. Guru berperan dalam meningkatkan kualitas pendidikan sebagai sumber daya manusia, dan guru merupakan ujung tombak dalam proses belajar mengajar. Oleh karena itu, guru dituntut untuk lebih kreatif dalam menemukan model, metode, dan strategi baru (Nata, 2011: 85).

Berdasarkan observasi awal peneliti di lapangan, terdapat beberapa gejala yang menyebabkan kegiatan belajar mengajar di sekolah kurang optimal, antara lain: a) guru jarang menggunakan media dalam proses pembelajaran, b) penerapan strategi pembelajaran yang tidak tepat, c) konsentrasi siswa dalam belajar kurang, d) kegiatan pembelajaran di kelas tidak merata, didominasi oleh anak cerdas, e) hasil belajar siswa yang rendah, dan masih banyaknya siswa yang tidak mau mengutarakan pendapatnya dalam proses pembelajaran; dan g) kurangnya sarana dan prasarana di dalam kelas.

Dalam proses belajar mengajar, guru harus memiliki strategi yang mendukung pembelajaran siswa secara efektif dan efisien untuk mencapai tujuan pembelajaran. Guru harus menguasai teknik presentasi atau metode dan model pengajaran yang efektif.

Salah satu alternatif untuk meningkatkan motivasi dan hasil belajar siswa dalam pembelajaran matematika adalah dengan menerapkan model pembelajaran yaitu model pembelajaran kooperatif (Delpika dkk, 2019; Guslinda \& Witri, 2018; Lazim dkk, 2018, Marhadi dkk, 2018). Model ini dapat membantu guru menjelaskan materi kepada siswa sehingga siswa dapat dengan mudah 
memahaminya. Picture and picture adalah salah satu tipe pembelajaran kooperatif yang dapat meningkatkan hasil belajar siswa. Hasil penelitian yang dilakukan oleh Nadya (2018) menunjukkan adanya peningkatan hasil belajar matematika kelas 1 melalui model pembelajaran picture and picture di SDN 37 Pekanbaru. Penelitian Nurrahmah (2018) pada kelas $\vee$ pada materi bilangan bulat menunjukkan bahwa model pembelajaran picture and picture di MIN 16 Aceh Besar juga menunjukkan adanya peningkatan hasil belajar siswa.

Hasil observasi dan dokumentasi dengan guru kelas IVB SDN 136 Pekanbaru ditemukan bahwa siswa kurang merespon pembelajaran yang disampaikan guru. Siswa tidak berperilaku sesuai harapan dalam proses pembelajaran. Siswa sering membuat keributan di kelas sehingga pada saat ada tugas, siswa cenderung tidak selesai mengerjakannya. Nilai rata-rata kelas menurun sehingga banyak siswa yang mendapat nilai dibawah Kriteria Ketuntasan Minimal (KKM). Dari 40 siswa, hanya 17 siswa (42,5\%) yang mencapai nilai KKM di atas 75 , sedangkan sisanya (57,5\%) tidak mencapai KKM.

Atas dasar latar belakang masalah yang diuraikan, maka peneliti melakukan penelitian tindakan sebagai upaya untuk melakukan perbaikan pembelajaran. Rumusan masalah penelitian ini adalah, bagaimana kapasitas hasil belajar dan aktivitas siswa setelah menerapkan pembelajaran matematika dengan model pembelajaran kolaboratif Picture and picture? Dan bagaimana dengan aktivitas guru setelah menggunakan pembelajaran matematika dengan model pembelajaran kooperatif tipe Picture and picture?

Model pembelajaran kooperatif tipe picture and picture adalah model pembelajaran yang menggunakan gambar dipasangkan atau diurutkan menjadi urutan logis (Suprijono, 2013). langkah-langkah dari pelaksanaan model pembelajaran kooperatif picture and picture diuraikan pada tabel 1.

Tabel 1. Langkah-langkah model pembelajaran kooperatif tipe picture and picture. 
1. Melakukan apersepsi Guru menyampaikan materi pengantar, tujuan Menyampaikan pembelajaran /kompetensi pembelajaran di tujuan pembelajaran awal pembelajaran.

dan melakukan apersepsi.

2. Menyiapkan media Guru menyediakan gambar-gambar terkait pembelajaran. dengan materi pembelajaran.

3. Mengorganisasikan Guru membagi siswa kedalam kelompoksiswa kedalam kelompok kecil yang heterogen. kelompok kooperatif.

4. Menjelaskan cara Guru menunjuk siswa untuk memasangkan menggunakan media atau mengurutkan gambar-gambar yang telah pembelajaran. disediakan.

5. Membimbing Guru menampilkan beberapa gambar yang kelompok belajar dan harus diurutkan atau dipasangkan oleh siswa, bekerja dan meminta tiap kelompok berdiskusi untuk mengurutkan gambar menjadi suatu rangkaian urutan materi.

6. Evaluasi

Guru meminta tiap-tiap kelompok mempresentasikan hasil kerja mereka dan berdiskusi terkait hal itu.

7. Memberikan Penghargaan Guru memberi penghargaan kepada siswa baik secara individu maupun kelompok.

Berdasarkan penjelasan tabel 1, dapat dipahami bahwa guru berperan menyampaikan kompetensi yang ingin dicapai, menyampaikan materi sebagai pengantar. Setelah itu guru menunjukkan atau memperlihatkan gambar-gambar yang berkaitan dengan materi. Siswa tidak hanya mendengar dan membuat catatan, tapi guru memanggil siswa secara bergantian memasang atau 
mengurutkan gambar-gambar yang berkenaan dengan materi pokok pembelajaran.

\section{METODE PENELITIAN}

Penelitian ini dilaksanakan di SD Negeri 136 Pekanbaru pada semester ganjil tahun ajaran 2019/2020. Penelitian ini di lakukan mulai tanggal 30 September sampai dengan tanggal 14 Oktober 2019. Rancangan penelitian yang dilakukan adalah penelitian tindakan kelas (PTK). PTK adalah penelitian yang bertujuan untuk memperbaiki pembelajaran dan dilakukan oleh guru melalui refleksi diri (Aqib dkk, 2008: 3).

PTK dalam studi ini dilaksanakan sebanyak 2 siklus. Setiap siklus terdiri dari 2 pembelajaran dan 1 kali ulangan harian. Tahapan PTK pada penelitian ini terdiri dari (1) Perencanaan, (2) Pelaksanaan, (3) Pengamatan, dan (4) Refleksi.

Subjek penelitian ini adalah 40 orang siswa kelas IVB SD Negeri 136 Pekanbaru. Siswa tersebut terdiri dari 20 orang laki-laki dan 20 orang perempuan.

Instrumen dalam penelitian terdiri dari Silabus, Rencana Pelaksanaan Pembelajaran (RPP), dan Lembar kerja peserta didik (LKPD). Instrumen pengumpulan data terdiri dari lembar observasi dan tes. Lembaran observasi terdiri dari lembar observasi aktivitas guru dan lembar observasi aktivitas siswa. Teknik pengumpulan data pada penelitian ini adalah dengan pengamatan aktivitas guru dan aktivitas siswa oleh observer, serta tes hasil belajar.

Data yang diperoleh dari penelitian ini dianalisis dengan menggunakan teknik penelitian deskriptif dengan penghitungan persentase.Sementara itu, data kualitatif digambarkan dengan analisis deskriptif, sedangkan data kuantitatif dianalisis dan dikelompokkan sesuai kriteria pada tabel 1 (Purwanto, 2013).

Tabel 1. Interval dan Kategori Aktivitas Guru dan Aktivitas Siswa

\begin{tabular}{cc}
\hline Presentase Interval (\%) & Kategori \\
\hline $86-100$ & Sangat Baik \\
$76-85$ & Baik \\
$60-75$ & Cukup \\
$55-59$ & Kurang \\
$<54$ & Kurang Sekali \\
\hline
\end{tabular}




\section{HASIL PENELITIAN}

\section{Pelaksanaan Pembelajaran}

Proses pembelajaran penelitian tindakan kelas pada setiap pertemuan di siklus I dan siklus II dilaksanakan sesuai fase - fase model pembelajaran kooperatif. Pada setiap pertemuan, fase - fase guru dalam melaksanakan penelitian tindakan kelas antara lain sebagai berikut :

Fase 1 (Menyampaikan Tujuan dan Memotivasi Peserta Didik).

Sebelum memulai proses pembelajaran, guru membuka pembelajaran dengan mengucapkan salam, kemudian meminta ketua kelas untuk memimpin teman-temannya membaca doa sebelum pelajaran dimulai secara bersama-sama, selanjutnya guru mengabsen siswa. Peneliti kemudian melakukan appersepsi melalui pertanyaan mengenai materi pelajaran yaitu: "anak-anak sekalian, pernahkah melihat bangun datar yang merupakan segi banyak dan bukan segi banyak?" , rata-rata banyak siswa menjawab pernah dan guru bertanya lagi "apa contoh bangun datar yang merupakan segi banyak dan bukan segi banyak?". Siswa banyak menjawab papan tulis, papan absen, lemari, dan jam, dapat dilihat pada gambar dibawah ini salah satu siswa yang duduk dibaris kedua sebelah kanan, mengangkat tangan dan memberi jawaban papan tulis. Peneliti menulis judul materi pelajaran kemudian menyampaikan tujuan dari mempelajari materi tersebut kemudian peneliti memotivasi siswa terkait pentingnya mempelajari materi tersebut.

Fase 2 (Menyajikan Informasi).

Guru menyajikan materi tentang mengelompokkan bangun datar antara segi banyak dengan yang bukan segi banyak berdasarkan sifat-sifatnya kepada siswa. Setelah itu guru bertanya jawab dengan siswa, dan meminta beberapa siswa untuk maju ke depan menempelkan beberapa gambar bangun datar antara segi banyak dengan yang bukan segi banyak berdasarkan sifat-sifatnya dan mengelompokkan gambar tersebut (Gambar 2). Setelah itu guru bertanya jawab 
kepada siswa "bangun datar apa saja lagi yang ada di dalam kelas?" dan meminta beberapa siswa untuk maju ke depan untuk menjawab soal yang diberikan guru dan guru meminta beberapa siswa kedepan untuk mengelompokkan bangun datar tersebut kedalam 2 kelompok dapat terlihat pada gambar dibawah ini. Tujuannya untuk memastikan apakah siswa telah memahami atau belum memahami materi yang disajikan oleh guru.

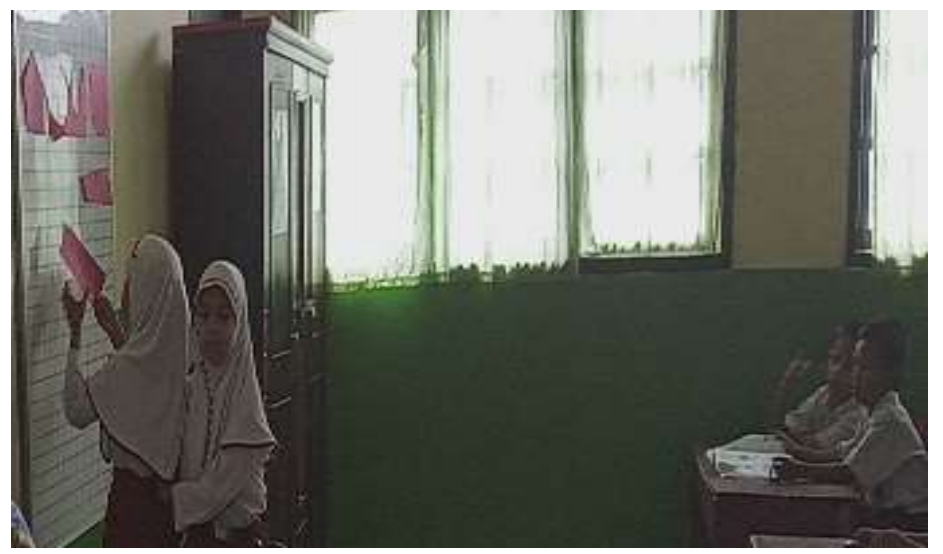

Gambar 2. Dua orang siswa yang sedang mengelompokkan bangun datar segi banyak dengan yang bukan segi banyak

Fase 3 (Mengorganisasikan siswa ke dalam kelompok).

Guru mengorganisasikan siswa kedalam kelompok belajar yang heterogen berdasarkan jenis kelamin dan tingkatan akademik. Setiap Kelompok beranggotakan 5 orang siswa. Guru membacakan nama anggota tiap kelompok belajar, kemudian mengorganisasikan siswa dalam menentukan tempat duduk masing-masing kelompok belajar. Pada saat guru mengorganisasikan siswa dalam kelompok belajar, banyak siswa yang bingung dan bertanya-tanya kepada guru sehingga kelas menjadi ribut. Ada juga siswa yang tidak ingin satu kelompok dengan temannya. Agar siswa tidak bingung, tidak ribut dan tidak bertanya-tanya lagi, guru membacakan nama anggota tiap kelompok sekali lagi. Setelah siswa duduk di kelompoknya masing-masing guru membagikan Lembar Kerja Peserta Didik 1 (LKPD) kepada setiap kelompok. Setelah semua kelompok mendapatkan LKPD, guru menginstruksikan untuk mengisi identitas yang terdapat pada LKPD berupa nama kelompok, nama anggota kelompok dan tanggal. Kemudian guru 
menjelaskan kegiatan yang akan dilakukan siswa selama mengerjakan LKPD. Guru juga menyampaikan alokasi waktu pengerjaan LKPD.

Fase 4 (Membimbing siswa dalam kelompok belajar)

Peneliti berjalan ke setiap kelompok untuk mengawasi dan membimbing kelompok yang mengalami kesulitan dalam mengerjakan soal pada lembar kerja peserta didik tersebut (Gambar 3). Pada pertemuan pertama siklus I masih banyak siswa yang belum paham mengerjakan soal pada lembar kerja peserta didik pada kelompoknya, sehingga peneliti menjelasakannya disetiap kelompok. Peneliti meminta perwakilan disetiap kelompok untuk mengumpulkan lembar kerja peserta didik jika sudah di jawab oleh siswa.

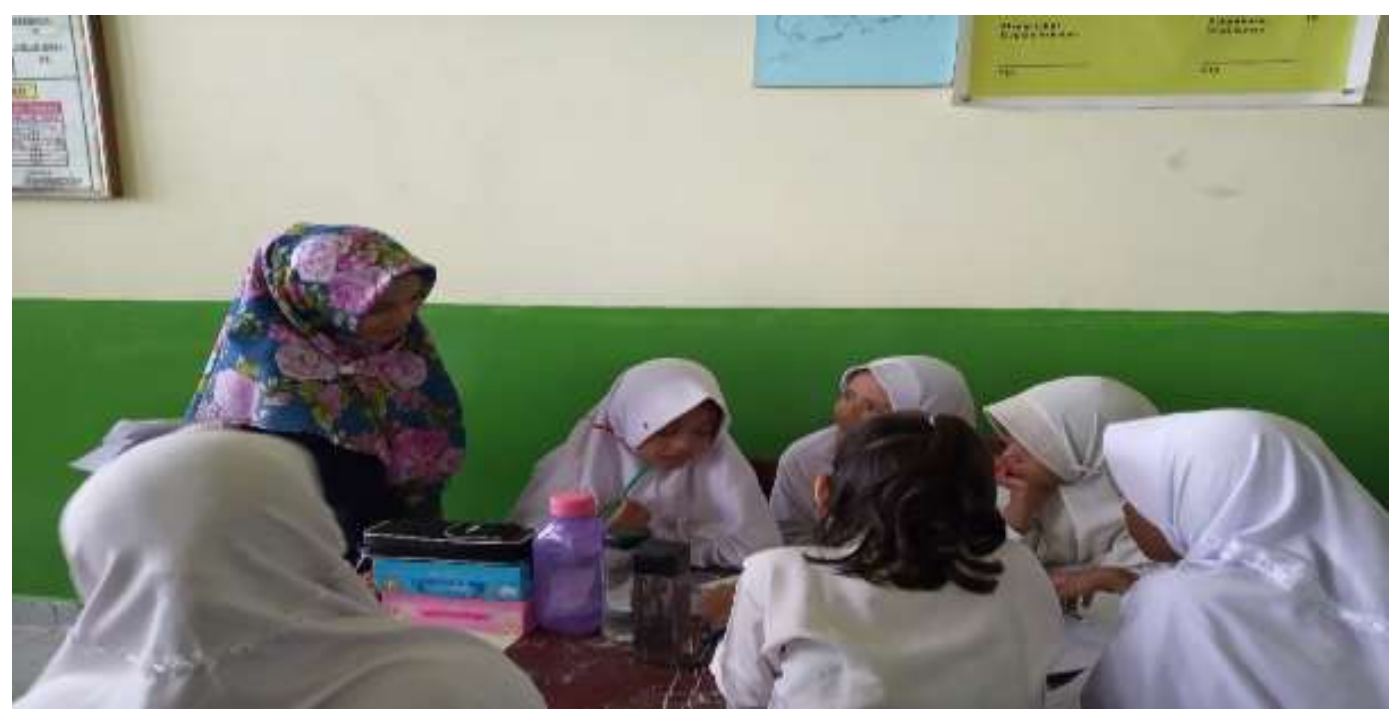

Gambar 3. Membimbing siswa dalam kelompok belajar

Fase 5 (Evaluasi).

Guru meminta perwakilan kelompok II untuk mempresentasikan hasil diskusi mereka didepan kelas, dan kelompok yang lain menanggapi hasil kerja kelompok penyaji dapat terlihat pada gambar dibawah ini (Gambar 4). Pada pertemuan ini masih banyak kelompok yang malu dan kurang percaya diri untuk menanggapi hasil diskusi kelompok penyaji. Hanya kelompok I dan kelompok $V$ saja yang berani dan mau menanggapi hasil diskusi kelompok penyaji. 
Selanjutnya peneliti memberikan evaluasi berupa 5 buah soal uraian untuk di kerjakan siswa secara individu.

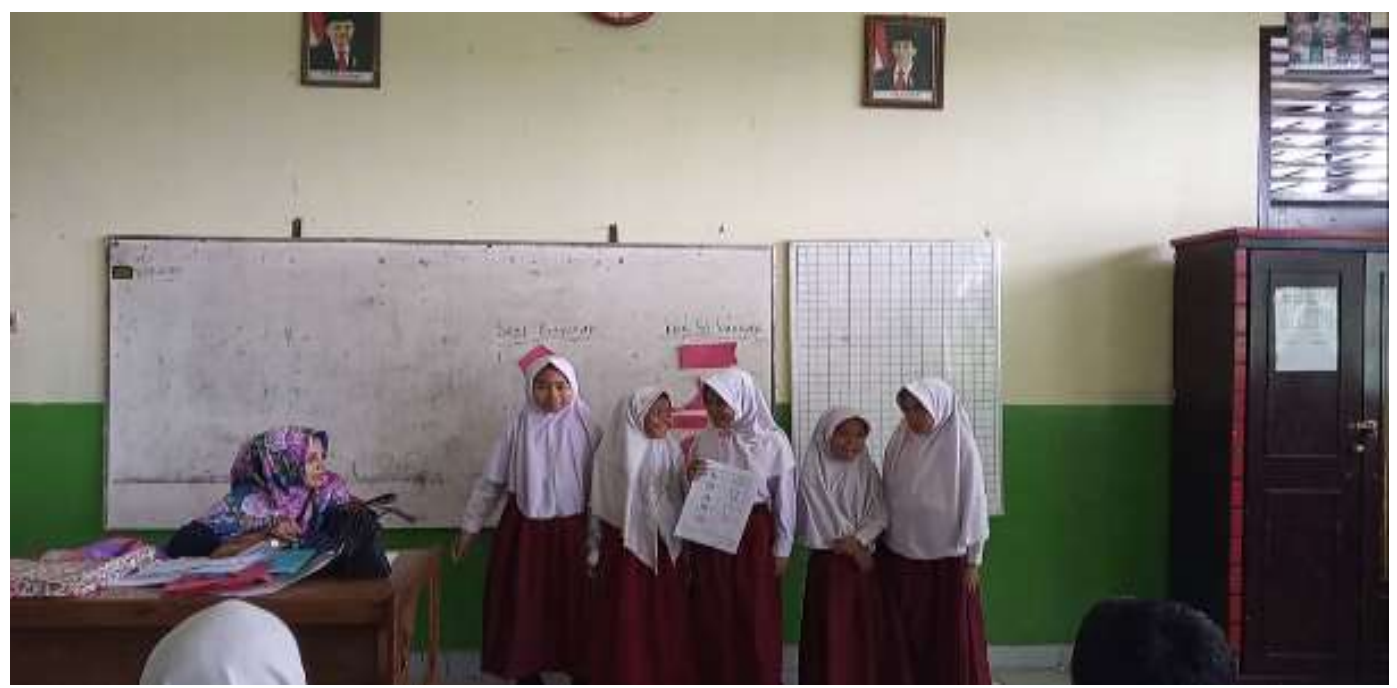

Gambar 4. Membimbing siswa dalam menyajikan hasil kelompoknya

Fase 6 (Memberikan Penghargaan dan Penutup).

Guru memberikan kata-kata pujian dan tepuk tanggan kepada kelompok yang aktif dan tertib dalam kelompok serta yang aktif dalam menanggapi hasil diskusi kelompok lain. Langkah pertama yang dilakukan guru yaitu meminta seorang siswa maju kedepan kelas untuk menyimpulkan materi yang telah berjalan hari ini. Hal ini terlihat pada gambar dibawah ini yang mana seorang siswa sedang menjelaskan pada teman-temannya. Kemudian guru membantu siswa untuk menyimpulkan materi yang telah dipelajari.

\section{Aktivitas Guru}

Dalam melaksanakan langkah-langkah pembelajaran pada pertemuan pertama, aktivitas guru masih belum sesuai dengan rencana pembelajaran yang disusun. Dalam pembelajaran ini masih banyak kelemahan dan kekurangan yang ditemui dalam pelaksanaannya. Pada saat mengorganisasikan siswa dalam kelompok siswa banyak yang ribut dan tidak teratur. Perhatian guru terhadap siswa yang bekerja dalam kelompok masih belum menyeluruh apalagi saat memberikan pengarahan kepada siswa yang memerlukan bantuan sehingga 
kelompok yang lain kurang terperhatikan sehingga mereka sering bergurau dan main-main dalam kelompok sehingga alokasi waktu tidak sesuai dengan yang diharapkan.

Pengamatan pada pertemuan kedua ini aktivitas guru sudah mulai membaik dari pertemuan pertama namun masih terdapat kelemahan, karena pada pertemuan ini guru sudah menyampaikan langkah-langkah pembelajaran dengan runtun dan sudah mengalokasikan waktu dengan baik. Guru tidak memerlukan waktu banyak untuk mengorganisasikan dalam kelompok karena siswa sudah mengetahui kelompoknya masing-masing karena guru hanya membimbing dan membantu beberapa kelompok saja.

Pada pertemuan ketiga dilaksanakan UH siklus I. Kegiatan ini tidak diamati oleh observer.

Pengamatan pada pertemuan keempat, aktivitas guru sudah dikategorikan sangat baik. Pembelajaran sudah mengalami peningkatan dibandingkan pertemuan sebelumnya di siklus I. Sementara itu, pada pertemuan kelima, aktivitas guru sudah sesuai dengan rencana pembelajaran dan fase-fase yang ditetapkan. Pada pertemuan keenam dilaksankan UH siklus II. Kegiatan ini tidak diamati oleh observer. Peningkatan hasil aktivitas guru disajikan pada gambar 5 .

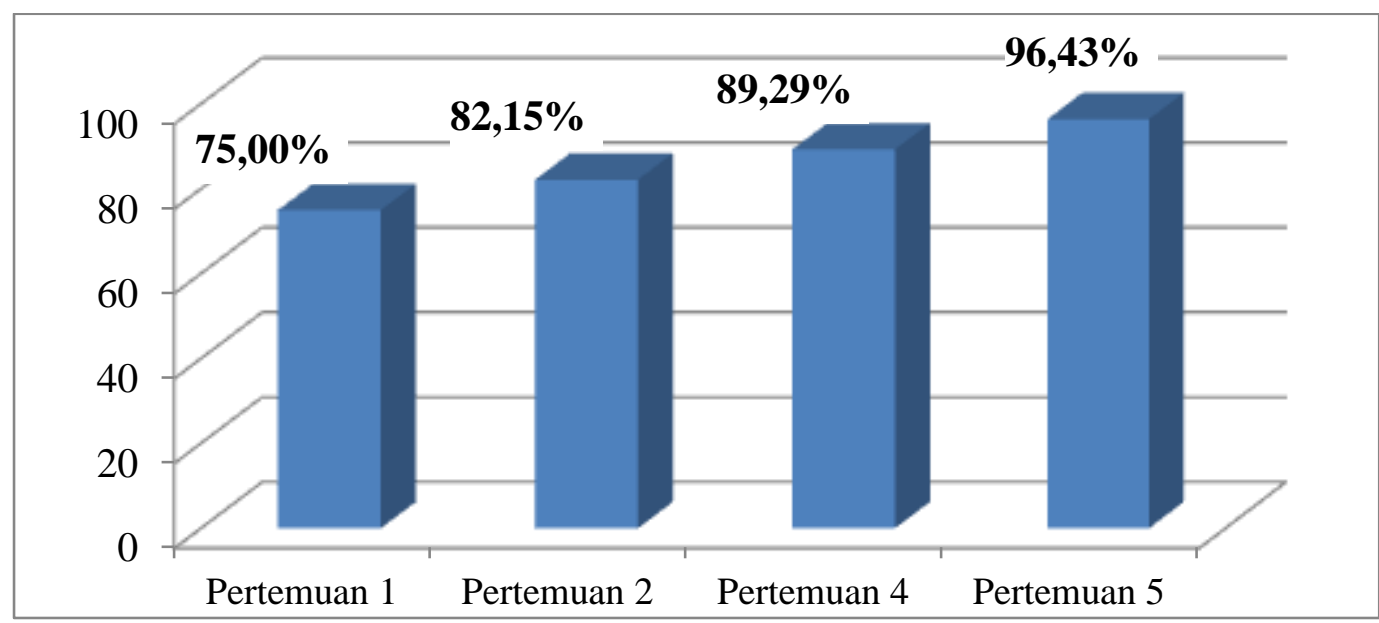

Gambar 5. Persentase Aktivitas Guru Siklus I dan Siklus II dalam Penerapan Model Pembelajaran Kooperatif Tipe Picture and picture 
Deskripsi untuk masing-masing aktivitas yang diamati berdasarkan kriteria penilaiam aktivitas guru disajikan sebagai berikut:

- Pada pertemuan I semua aktivitas guru mendapat skor 3. Karena guru menyampaikan tujuan pembelajaran dan memotivasi siswa tetapi kurang sesuai dengan materi pelajaran.

- Pada pertemuan II semua aktivitas guru mendapat skor 3 kecuali evaluasi dan penghargaan karena guru mendapatkan nilai 4 dikarenakan siswa melaksanakan evaluasi dan penghargaan dengan sangat baik.

- Pada pertemuan IV semua aktivitas guru mendapat skor 4 menyajikan informasi materi pembelajaran, memberikan evaluasi dan penguatan tentang bangun datar, merangkum pelajaran dan memberi penguatan kepada siswa, dan memberikan penghargaan dikarenakan siswa melaksanakan evaluasi dan penghargaan dengan sangat baik namun masih mendapatkan skor 3 menyampaikan tujuan pembelajaran dan memotivasi siswa, mengorganisasi siswa dalam kelompok kemudian membagikan LKPD dan media pembelajaran serta menjelaskan cara penggunaan media, dan memantau dan membimbing siswa dalam kelompok

- Pada pertemuan V semua aktivitas guru mendapat skor 4 kecuali mengorganisasi siswa dalam kelompok kemudian membagikan LKPD dan media pembelajaran serta menjelaskan cara penggunaan media karena guru mendapatkan nilai 3 dikarenakan guru masih belum terlalu bisa menguasai kelas

Secara umum aktivitas guru pada setiap pertemuan di siklus I dan II mengalami peningkatan. Peningkatan persentase pada pertemuan pertama ke pertemuan kedua meningkat sebesar 7,15\%. Pada pertemuan kedua ke pertemuan keempat meningkat sebesar $4,46 \%$. dan pada pertemuan keempat ke pertemuan kelima meningkat sebesar $9,82 \%$. Untuk kategori peningkatan tiap siklus dapat dilihat bahwa pada siklus I dikategorikan baik dan pada siklus II dikategorikan sangat baik. Jadi, dapat disimpulkan bahwa aktivitas guru disetiap pertemuan dari siklus I ke siklus II meningkat. 


\section{Aktivitas Siswa}

Pada pertemuan pertama aktivitas siswa masih rendah dalam proses pembelajaran. Hal ini disebabkan siswa bingung duduk dalam kelompoknya sehingga membuat suasana kelas menjadi ribut. Siswa juga tidak bisa menerima teman yang ada dikelompoknya. Pada saat mengerjakan LKPD hanya beberapa kelompok saja yang aktif bertanya. Kelemahan juga terdapat pada saat siswa menyimpulkan pelajaran. Siswa terlihat kurang percaya diri dan malu-malu.

Pengamatan pada pertemuan kedua, aktivitas siswa sudah mulai baik dari pertemuan pertama. Tetapi pada saat mengerjakan LKPD masih ada beberapa kelompok yang tidak aktif dalam menyelesaikan LKPD dan ada juga yang mengerjakan secara individu. Pada saat menyimpulkan pelajaran siswa sudah mulai percaya diri meskipun masih ada sebagian yang malu-malu.

Pada pertemuan ketiga dilaksanakan UH siklus I. Kegiatan ini tidak diamati oleh observer.

Pada pertemuan keempat aktivitas siswa sudah mulai baik dan meningkat dari pertemuan sebelumnya di siklus I. Semangat belajar siswa juga meningkat. Pada pertemuan kelima, aktivitas pembelajaran siswa sudah terlaksana dengan sangat baik. Sudah sesuai dengan rencana pembelajaran dan langkah-langkah dalam pembelajaran kooperatif tipe Picture and picture. Pada pertemuan keenam dilaksanakan UH siklus II.

Aktivitas siswa ditiap pertemuan dari siklus I ke siklus II mengalamai peningkatan. Peningkatan aktivitas siswa disajikan pada gambar 6 .

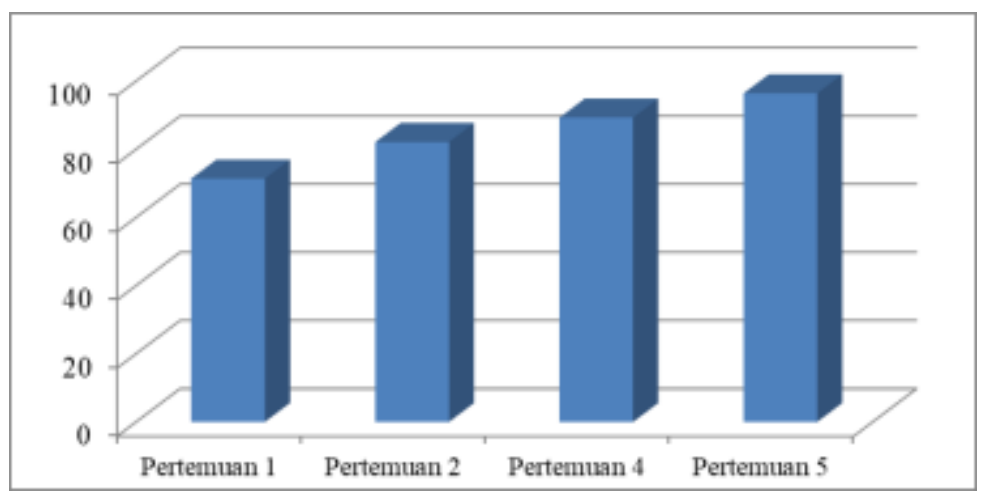

Gambar 6. Persentase Aktivitas Siswa Siklus I dan Siklus II dalam Penerapan Model Pembelajaran Kooperatif Tipe Picture and Picture 
Deskripsi untuk masing-masing aktivitas yang diamati berdasarkan kriteria penilaiam aktivitas siswa diuraikan sebagai berikut:

- Pada pertemuan I aktivitas siswa mendapat skor 2 pada tertib dalam kelompok mengerjakan tugas yang diberikan guru dalam LKPD dan diskusi dengan kelompok untuk menyatukan pendapat atau hasil jawaban dikarenakan siswa kurang sekali dalam fase ini, dan mendapatkan skor 3 pada Memperhatikan dan mendengarkan penyampaian tujuan pembelajaran oleh guru, memperhatikan dan mendengarkan penjelasan guru terhadap informasi / materi pembelajaran yang disampaikan guru, bimbingan guru merangkum materi pelajaran, dan tertib dan memperhatikan guru memberikan penghargaan dikarenakan siswa cukup dalam fase ini dan hanya fase mempresentasikan hasil diskusi kelompoknya evaluasi dan siswa secara mandiri mengerjakan evaluasi, siswa mendapatkan nilai 4.

- Pada pertemuan II aktivitas siswa hampir semuanya mendapat skor 3 hanya fase memperhatikan dan mendengarkan penjelasan guru terhadap informasi / materi pembelajaran yang disampaikan guru, dan mempresentasikan hasil diskusi kelompoknya evaluasi dan siswa secara mandiri mengerjakan evaluasi siswa mendapatkan nilai 4 dikarenakan siswa sangat baik dalam fase-fase ini.

- Pada pertemuan IV semua aktivitas siswa mendapat skor 4 Memperhatikan dan mendengarkan penyampaian tujuan pembelajaran oleh guru, mempresentasikan hasil diskusi kelompoknya evaluasi dan siswa secara mandiri mengerjakan evaluasi, dengan bimbingan guru merangkum materi pelajaran, dan Siswa tertib dan memperhatikan guru memberikan penghargaan dikarenakan siswa melaksanakan evaluasi dan penghargaan dengan sangat baik namun masih mendapatkan skor 3 memperhatikan dan mendengarkan penjelasan guru terhadap informasi / materi pembelajaran yang disampaikan guru, tertib dalam kelompok mengerjakan tugas yang diberikan guru dalam LKPD dan media pembelajaran serta menjelaskan cara penggunaan media, dan diskusi dengan kelompok untuk menyatukan pendapat atau hasil jawaban. 
- Pada pertemuan $\mathrm{V}$ semua aktivitas siswa mendapat skor 4 kecuali tertib dalam kelompok mengerjakan tugas yang diberikan guru dalam LKPD nilai 3 dikarenakan siswa masih belum tertib mengerjakan tugas dalam kelompok.

Secara umum aktivitas siswa pada setiap pertemuan di siklus I dan II mengalami peningkatan. Peningkatan persentase pada pertemuan pertama ke pertemuan kedua meningkat sebesar 10,72\%. Pada pertemuan kedua ke pertemuan keempat meningkat sebesar 7,15\%. Dan pada pertemuan keempat ke pertemuan kelima meningkat sebesar $7,13 \%$. Untuk kategori peningkatan tiap siklus dapat dilihat bahwa pada siklus I dikategorikan baik dan pada siklus II dikategorikan sangat baik. Jadi, dapat disimpulkan bahwa aktivitas siswa ditiap pertemuan dari siklus I ke siklus II meningkat.

\section{Aktivitas Siswa}

Peningkatan hasil belajar matematika siswa melalui penerapan model pembelajaran kooperatif tipe Picture and Picture disajikan pada tabel 1.

Tabel 1. Peningkatan Rata-Rata Hasil Belajar Matematika Siswa Kelas IVB SD Negeri 136 Pekanbaru.

\begin{tabular}{|c|c|c|c|c|c|}
\hline \multirow[t]{2}{*}{ No } & \multirow[t]{2}{*}{ Data } & \multirow[t]{2}{*}{$\begin{array}{c}\text { Jumlah } \\
\text { Siswa }\end{array}$} & \multirow[t]{2}{*}{$\begin{array}{l}\text { Rata- } \\
\text { Rata }\end{array}$} & \multicolumn{2}{|c|}{$\begin{array}{c}\text { Peningkatan Hasil Belajar } \\
\text { Siswa }\end{array}$} \\
\hline & & & & SD-UH I & SD-UH II \\
\hline 1. & Skor Dasar & 40 & 68,25 & $13,26 \%$ & \\
\hline 2. & $\mathrm{UHI}$ & 40 & 77,3 & & $24,54 \%$ \\
\hline 3. & UH II & 40 & 85 & & \\
\hline
\end{tabular}

Nilai rata-rata siswa sebelum tindakan yaitu 68,25 dengan kategori cukup. Kemudian pada siklus I meningkat menjadi 77,3 dan siklus II menjadi 85. Rata rata hasil belajar matematika siswa meningkat namun pada siklus I ketuntasan klasikal setelah dilakukan tindakan hanya diperoleh $72,5 \%$. Karena siklus I belum tuntas sehingga dilakukan kembali tindakan pada siklus II, pada siklus ini baru diperoleh ketuntasan klasikal $87,5 \%$ dan kategori tuntas dengan rata-rata 85 . 


\section{PEMBAHASAN}

Pembahasan dalam penelitian ini dimaksudkan untuk menjawab rumusan masalah dalam penelitian ini. Hasil penelitian ini secara umum menunjukkan bahwa terjadi peningkatan aktivitas guru dan siswa setelah dilaksanakan pembelajaran matematika pada materi bangun datar. Hasil belajar siswa pada materi bangun datar juga mengalami peningkatan sehinngga kentutasan klasikal siswa yang rendah sebelum dilaksankan tindakan mengalami peningkatan setelah dilaksanakan tindakan.

Meningkatnya hasil belajar siswa tidak terlepas dari peran guru dalam pelaksanaan pembelajaran. Sesuai dengan pendapat Isjoni (2015:61) bahwa guru memiliki peranan penting dalam proses pembelajaran. Guru dituntuk untuk menciptakan lingkungan yang optimal baik secara fisik maupun secara mental. Lebih lanjut Isjoni (2015:23) mengemukakan bahwa pelaksanaan pembelajaran dengan menggunakan model pembelajaran kooperatif memungkinkan siswa dapat meraih keberhasilah dalam belajar. Selain itu, pembelajaran kooperatif melatih siswa untuk memiliki keterampilan berpikir dan keterampilan sosial. Hal ini ditunjukkan dalam studi ini dimana siswa lebih aktif belajar dan meningkatkan interaksi sosial mereka.

Hasil studi ini juga sejalan dengan hasil studi yang dilakukan oleh Nadya (2018) yang berjudul penerapan model pembelajaran kooperatif tipe picture and picture untuk meningkatkan hasil belajar matematik siswa kelas IA SDN 37 Pekanbaru tahun ajaran 2017/2018". Hal yang sama juga ditunjukkan oleh hasil studi Nurrahmah (2018) yang berjudul "penerapan model pembelajaran kooperatif tipe picture and picture untuk meningkatkan hasil belajar matematik siswa kelas VA MIN 16 Aceh Besar tahun ajaran 2017/2018". Dari hasil-hasil studi tersebut dan didukung oleh studi yang peneliti lakukan maka dapat disimpulkan bahwa penerapan model pembelajaran kooperatif tipe picture and picture mampu meningkatkan aktivitas dan hasil belajar siswa. 


\section{SIMPULAN DAN REKOMENDASI}

Penerapan model pembelajaran kooperatif tipe picture and picture dapat meningkatkan aktivitas guru, aktivitas siswa, dan hasil belajar siswa. Aktivitas guru meningkat dari kategori cukup pada pembelajaran pertama siklus I menjadi amat baik pada akhir pembelajaran siklus II. Begitu juga dengan aktivitas siswa yang meningkat dari kategori cukup pada pembelajaran pertama siklus I ke kategori amat baik pada pembelajaran akhir siklus II. Hasil belajar siswa juga mengalami peningkatan dari kategori kurang sebelum tindakan menjadi kategori baik setelah tindakan.

Berdasarkan penelitian yang telah dilakukan, maka peneliti memberikan rekomendasi yaitu model pembelajaran kooperatif tipe picture and picture diharapkan dapat menjadi salah satu alternatif model pembelajaran matematika disekolah guna meningkatkan aktivitas dan hasil belajar siswa. Model ini menuntut siswa untuk berperan aktif dalam proses pembelajaran. Mengingat penelitian ini masih pada skala yang kecil, yaitu di sebuah sekolah dan pada satu materi pembeljaran, penelitian selanjutnya dapat mengujicobakan model ini dengan ruang lingkup dan materi yang lebih luas.

\section{DAFTAR PUSTAKA}

Aqib, Z., dkk. (2011). Penelitian Tindakan Kelas untuk SD, SLB, dan TK. Bandung: CV. Yrama Widya.

Delpika, D. dkk. (2019). Penerapan model pembelajaran kooperatif tipe make and match untuk meningkatkan hasil belajar IPA siswa kelas IIIA SD Negeri 191 Pekanbaru. Tunjuk Ajar: Jurnal Penelitian Ilmu Pendidikan, 2(2), 123-133.

Guslinda, G., \& Witri, G. (2018). Penerapan model pembelajaran kooperatif tipe make and match untuk meningkatkan hasil belajar IPS siswa. Tunjuk Ajar: Jurnal Penelitian Ilmu Pendidikan, 1(1), 1-13.

Isjoni. (2015). Cooperatif Learning. Alfabeta. Bandung.

Lazim, N. dkk. (2018). Utilizing Cooperative Learning Model Types Make a Match toPromote Primary Students' Achivement in Science. Journal of Teaching and Learning in Elementary Education, 1(1), 11-19.

Marhadi, H. dkk. (2018). Effect of Cooperative Learning Model Type Course Review Horay (CRH) on Elementary Students' Learning Outcome in Social Subject. Journal of Teaching and Learning in Elementary Education, 1(1), 20-29. 
Nadya (2018). Penerapan Model Pembelajaran Kooperatif Tipe Picture and Picture Untuk Meningkatkan Hasil Belajar matematik Siswa Kelas IA SDN 37 Pekanbaru Tahun Ajaran 2017/2018. Skripsi tidak dipublikasikan. Universitas Riau.

Nata, A. (2011). Strategi Pembelajaran, Jakarta: Kencana.

Nurrahmah, C. (2018). Penerapan Model Pembelajaran Kooperatif Tipe Picture And Picture Untuk Meningkatkan Hasil Belajar matematik Siswa Kelas VA MIN 16 Aceh Besar Tahun Ajaran 2017/2018. Lincolin Arsyad, 3(2), 1-46. https://doi.org/http://dx.doi.org/110.21043/equilibrium.v3i2.1268

Purwanto, N. (2013). Prinsip-Prinsip dan Teknik Evaluasi Pengajaran.Remaja Rosdakarya.Bandung.

Putra, Z. H. (2019). Tantangan dan Peluang Guru SD dalam Pembelajaran Matematika Berbasis Teknologi Digital di Era Revolusi Industri 4.0. Dalam E. Noviana, N. Afendi, \& M. N. Huda (Eds.). Prosiding Seminar Nasional Pendidikan Guru Sekolah Dasar Fakultas Keguruan dan Ilmu Pendidikan Universitas Riau (vol. 1, pp. 7-19). Pendidikan Guru Sekolah Dasar Fakultas Keguruan dan Ilmu Pendidikan Universitas Riau http://dx.doi.org/10.33578/psn.v1i1.7766

Suprijono, A. (2013).Cooperatif Learning. Yogyakarta: Pustaka Pelajar.

Witri, G., Putra, Z. H., \& Nurhanida. (2015). Analisis kemampuan number sense siswa sekolah dasar di Pekanbaru. In Mahdum, S. S. Achmad, D. A. Natuna, Suarman, A. R. Ahmad, \& M. H. M. Yasin (Eds.), Proceeding of 7th International Seminar on Regional Education: Educational community and cultural diversity (vol. 2 pp. 755-762). Pekanbaru: Universitas Riau Press. https://ejournal.unri.ac.id/index.php/ISRE/article/view/3091

Witri, G., Putra, Z. H., \& Gustina, N. (2014). Analisis kemampuan siswa sekolah dasar dalam menyelesaikan soal-soal matematika model the trends for international mathematics and science study (TIMSS) di Pekanbaru. Primary: Jurnal Pendidikan Guru Sekolah Dasar, 3(1), 32-39. http://dx.doi.org/10.33578/jpfkip.v3i1.2111 